Revista de Biología Marina y Oceanografía

Vol. 48, №3: 613-622, diciembre 2013

DOI 10.4067/S0718-19572013000300017

Article

\title{
Diet plasticity of the South American sea lion in Chile: stable isotope evidence
}

Plasticidad de la dieta del lobo marino común en Chile: evidencia mediante isótopos estables

\author{
Lily Muñoz ${ }^{1}$, Guido Pavez ${ }^{1}$, Renato A. Quiñones ${ }^{2,3}$, Doris Oliva ${ }^{1}$, \\ Macarena Santos ${ }^{1,4}$ and Maritza Sepúlveda ${ }^{1}$
}

\begin{abstract}
${ }^{1}$ Centro de Investigación y Gestión de los Recursos Naturales (CIGREN), Instituto de Biología, Facultad de Ciencias, Universidad de Valparaíso, Av. Gran Bretaña 1111, Playa Ancha, Valparaíso, Chile. lily.munozp@gmail.com ${ }^{2}$ Programa de Investigación Marina de Excelencia (PIMEX), Facultad de Ciencias Naturales y Oceanográficas, Casilla 160C, Universidad de Concepción, Chile

${ }^{3}$ Interdisciplinary Center for Aquaculture Research (INCAR-FONDAP), Universidad de Concepción, O’Higgins 1695, Concepción, Chile

${ }^{4}$ Centro de Investigación Eutropia, Ahumada 131 Oficina 912, Santiago, Chile
\end{abstract}

\begin{abstract}
Resumen.- Estudios de dieta del lobo marino común (LMC) en Chile sugieren que esta especie es un depredador oportunista y generalista, cuya dieta varía dependiendo de la distribución de las especies presas y de las variaciones espaciotemporales en la abundancia de dichas presas. Sin embargo, estos estudios han sido esporádicos, limitados espacialmente y basados en análisis de contenidos estomacales, lo que no permite un análisis integral de la composición de la dieta y de sus potenciales diferencias espacio-temporales. En este estudio se analizó la composición de la dieta del LMC en 3 zonas geográficas de la costa chilena utilizando los isótopos estables de $\delta^{13} \mathrm{C}$ y $\delta^{15} \mathrm{~N}$ en muestras de pelo y piel. En la zona norte las principales especies consumidas fueron los peces Isacia conceptionis $(19,5 \%)$ de acuerdo al análisis de piel y Cilus gilberti $(23,3 \%)$ en análisis de pelo; en la zona centro lo fueron Thyrsites atun $(40,1 \%)$ en piel y Strangomera bentincki $(31,1 \%)$ en pelo; mientras que en la zona sur especies de peces pelágicos (como T. atun y Trachurus murphyi, 20,8\%) en piel y salmones de cultivo $(20,7 \%)$ en pelo. Estas diferencias demuestran que el LMC muestra cambios espaciales en la composición de su dieta. Variaciones entre tejidos, así como con lo registrado en estudios previos, sugiere que esta especie es capaz de adaptarse a variaciones, tanto intra como inter-anuales, de la presencia/ausencia de sus presas.
\end{abstract}

Palabras clave: Modelos mixtos, MixSir, especialización trófica, $\delta^{13} \mathrm{C}, \delta^{15} \mathrm{~N}$, Otaria flavescens, Chile

\begin{abstract}
Diet studies of the South American sea lion (SASL) in Chile suggest that this species is an opportunistic and generalist predator whose diet varies depending on the distribution of prey species and spatial and temporal variations in the abundance of these dams. However, these studies have been sporadic, geographically limited and based on stomach content analysis, which does not allow an integral analysis of the composition of the diet of this species and its potential spatial and temporal variability. In this study we analyzed the diet of the SASL in 3 geographic zones of the coast of Chile using analysis of stable isotopes $\delta^{13} \mathrm{C}$ and $\delta^{15} \mathrm{~N}$ on hair and skin tissues. In the northern zone, the main prey species consumed by SASL were Isacia conceptionis (19.5\%) for skin and Cilus gilberti $(23.3 \%)$ for hair; in the central zone were Thyrsites atun $(40.1 \%)$ for skin and Strangomera bentincki $(31.1 \%)$ for hair, whereas in the southern zone the main species were pelagic fish (such as T. atun and Trachurus murphyi, 20.8\%) for skin and farm-raised salmonids (20.7\%) for hair analysis. These differences indicate variation in the composition of its diet. Variations between the analyzed tissues and also with previous studies suggest that this species is capable of adapting to intra- and inter-annual variations in the presence/absence of its prey.
\end{abstract}

Key words: Mixed models, MixSir, Trophic specialization, $\delta^{13} \mathrm{C}, \delta^{15} \mathrm{~N}$, Otaria flavescens, Chile

\section{INTRODUCTION}

South American sea lions (SASL) Otaria flavescens (Shaw, 1800) are considered as generalist predators (Capozzo \& Perrin 2009), with a diet primarily composed by fish and to a lesser degree by mollusks and crustaceans (VazFerreira 1982, Crespo et al. 1997, Koen Alonso et al. 2000). In Chile, Sielfeld et al. (1997) found that in the extreme northern part of Chile $\left(18^{\circ} 30^{\prime} \mathrm{S}-26^{\circ} 05^{\prime} \mathrm{S}\right)$ the diet was composed mainly by pelagic species such as anchovy (Engraulis ringens) and Patagonian squid (Loligo gahi). Aguayo \& Maturana (1973) reported that in the central zone, the Patagonian redfish (Sebastes oculatus), the South Pacific hake (Merluccius gayi gayi) and the Araucanian herring (Strangomera bentinckii) were the main prey items, while in the south-central zone ( $36^{\circ} 30^{\prime} \mathrm{S}$ - 
$\left.38^{\circ} \mathrm{S}\right)$ benthodemersal species such as the South Pacific hake and the pink cusk-eel (Genypterus blacodes) (GeorgeNascimento et al. 1985) were the most common prey. This variation suggests that the SASL is an opportunistic and generalist predator, and that the composition of its diet will depend upon the local abundance of prey species (Aguayo \& Maturana 1973, Crespo et al. 1997, Koen Alonso et al. 2000, Cappozzo \& Perrin 2009). However, all these studies have been sporadic, geographically limited and based only on stomach content analysis, which does not allow for an integrated analysis of SASL diet composition and its potential spatial and temporal variability.

Stomach content and scat analyses are the most common and traditionally utilized methods for the reconstruction of the diet in marine mammals (Barros \& Clarke 2009). The main advantage of these methods is that they quantify the relative number and size of prey species through identification of hard structures (e.g., otoliths, bones, scales, cephalopod beaks) (Hobson et al. 1997). Stomach and scat analyses, however, have a number of limitations. The main disadvantage of these traditional methods is that, unless the sampling frequency is high, each analysis represents a view of the food eaten only during the most recent feeding bout, and does not necessarily reflect the time integrated representation of diet composition (Hobson et al. 1994). Errors may also be introduced by factors such as selective retention of remains (e.g., cephalopod beaks versus fish bones) and differential degradation of hard structures (Naya et al. 2000). Also, actually they are more expensive that other methods (e.g., stable isotopes) because they require more human labor (Newsome et al. 2010a). Due to these disadvantages, in recent decades other techniques have been developed to quantify diet composition in both terrestrial and marine consumers, including marine mammals.

Stable isotope analysis has quickly become a widely used tool to study trophic ecology and consumer diet composition (Kelly 2000, Fry 2006, Caut et al. 2009). This method is ideal for examining variation in the diet composition, since different tissues integrate dietary inputs over different time periods. For example, blood plasma and liver have a very rapid isotopic incorporation rate relative to whole blood or muscle (Martínez del Río et al. 2009). Turnover rate varies according to the metabolic activity of the tissue itself being analyzed, so that changes in the composition of the diet may take from a few days to several weeks to be reflected in the tissue of a predator
(Tieszen et al. 1983, Hobson \& Clark 1992). Thus most metabolically active tissues, such as skin, have a high turnover rate (Hicks et al. 1985), because they interact more with newly ingested nutrients and metabolites in the diet (Tieszen et al. 1983). Kurle \& Worthy (2001), in a study in terrestrial mammals, indicate that the half-life of carbon isotopes in the skin are among the values of the liver (6.4 days) and muscle (27.6 days). Additionally Hobson (1993) indicates that the isotopic analysis of a tissue represents an integration of the diet of 2-3 times the average life of the isotopes. That is, the skin of sea lions reflects the diet of the animals from twenty days to 3 months ago. Hair, by contrast, is an inert tissue that once synthesized does not show isotope replacement. Therefore, hair based studies reflect the composition of the diet of the animal in this period of time in which the tissue was synthesized (Newsome et al. 2009, Orr et al. 2011). Carbon $\left(\delta^{13} \mathrm{C}\right)$ and nitrogen $\left(\delta^{15} \mathrm{~N}\right)$ isotope values of a consumer reflect those of its diet, with a selective retention of the heavier isotope $\left({ }^{13} \mathrm{C}\right.$ or $\left.{ }^{15} \mathrm{~N}\right)$ and excretion of the lighter one $\left({ }^{12} \mathrm{C}\right.$ or ${ }^{14} \mathrm{~N}$ ) (Das et al. 2003). This selective retention/excretion yields a somewhat predictable isotopic difference between consumer and prey, also known as trophic discrimination (Karasov \& Martínez del Río 2007, Crawford et al. 2008). $\delta^{15} \mathrm{~N}$ values increase by $\sim 3-5 \%$ o per trophic step and thus they are used to quantify the position of a consumer in a trophic web, while values of $\delta^{13} \mathrm{C}$ are generally used to evaluate habitat use (e.g., nearshore versus offshore) in marine consumers (DeNiro \& Epstein 1978, 1981; Hobson et al. 1994).

The first ecological applications of stable isotopes considered only a qualitative comparison of isotope values that are commonly presented in $\delta^{13} \mathrm{C}$ versus $\delta^{15} \mathrm{~N}$ bivariate space (biplots). However, during the last decade more quantitative measures of trophic position and diet composition have been developed, such as the mixing models that can generate quantitative estimates of the proportional contribution of different prey sources to the diet of a consumer (Phillips \& Gregg 2003, Moore \& Semmens 2008, Parnell et al. 2010). Two of the most commonly used models are MixSIR (Moore \& Semmens 2008) and SIAR (Parnell et al. 2010). Both of these methods use Bayesian statistics and allow users to input isotopic variance (SD) in prey sources and error estimates for trophic discrimination factors.

Here we present the diet composition of the SASL based on isotopic data $\left(\delta^{13} \mathrm{C}\right.$ and $\delta^{15} \mathrm{~N}$ values) from skin and hair samples collected in northern, central, and 
southern zones of Chile. The objectives of this study were to: (1) analyze the diet composition of the SASL in these zones of Chile, and (2) determine if there are variations in the diet of this consumer between hair and skin tissues. These results provide novel insight into spatial and/or temporal variation in the diet composition of the SASL that inhabit Chilean waters.

\section{Materials AND METHODS}

\section{SAmple COLlection}

From February 2009 to January 2012, skin and hair samples were collected from 94 adult and subadult SASL individuals (48 males, 27 females, and 19 indeterminate) in 3 areas of the Chilean coast: Northern Zone including Isla Choros and Isla Chañaral $(n=12)$ collected in Summer and Autumn; Central Zone including Cobquecura $(n=$ 16) collected in Winter; and Southern Zone including different localities off Chiloé Island $(n=66)$ collected in Summer, Autumn months, Winter and Spring (Fig. 1). Samples were obtained with a modified PaxArms. 22 caliber rifle using darts specially designed to obtain a small sample of hair, skin and fat without harming the animal. In the same areas we also obtained muscle samples of 28 species of fish, mollusks and crustaceans which are potential prey of SASL in Chile (Table 1). All samples were kept frozen during transport to the laboratory.

\section{SAMPle ANALYSES}

In the laboratory, skin, hair and fat were separated and stored separately. Samples were dried in a drying oven (model UNE400, Memmert, Germany) at $60^{\circ} \mathrm{C}$ for $72 \mathrm{~h}$. Hair and skin samples were then minced with a scalpel and muscle samples (preys) ground in a porcelain mortar and stored in filter paper. Finally, lipids were removed from samples in a Soxhlet extractor with petroleum ether for $2 \mathrm{~h}$. Samples were then stored in microcentrifuge tubes prior to weighing for stable isotope analysis. A 0.5 ( \pm $0.05) \mathrm{mg}$ subsample of sea lion (hair and skin) and prey (muscle) tissues were sealed into tin capsules for stable isotope analysis. $\delta^{13} \mathrm{C}$ and $\delta^{15} \mathrm{~N}$ values were determined using a Carlo-ErbaNC 2500 (Milan, Italy) or Costech4010 (Valencia, California, USA) Elemental Analyzer interfaced with a Thermo-FinniganDelta Plus XL isotope ratio mass spectrometer (Waltham, Massachusetts, USA) at the University of Wyoming Stable Isotope Facility (Laramie, WY, USA). Isotopic results are expressed as $\delta$ values, $\delta^{13} \mathrm{C}$ or $\delta^{15} \mathrm{~N}=1000 \times\left[\left(R_{\text {smpl }}-R_{\text {stnd }}\right) / R_{\text {stnd }}\right]$, where $R_{\text {smpl }}$ and $R_{\text {stnd }}$ are the ${ }^{13} \mathrm{C} /{ }^{12} \mathrm{C}$ or ${ }^{15} \mathrm{~N} /{ }^{14} \mathrm{~N}$ ratios of the sample and

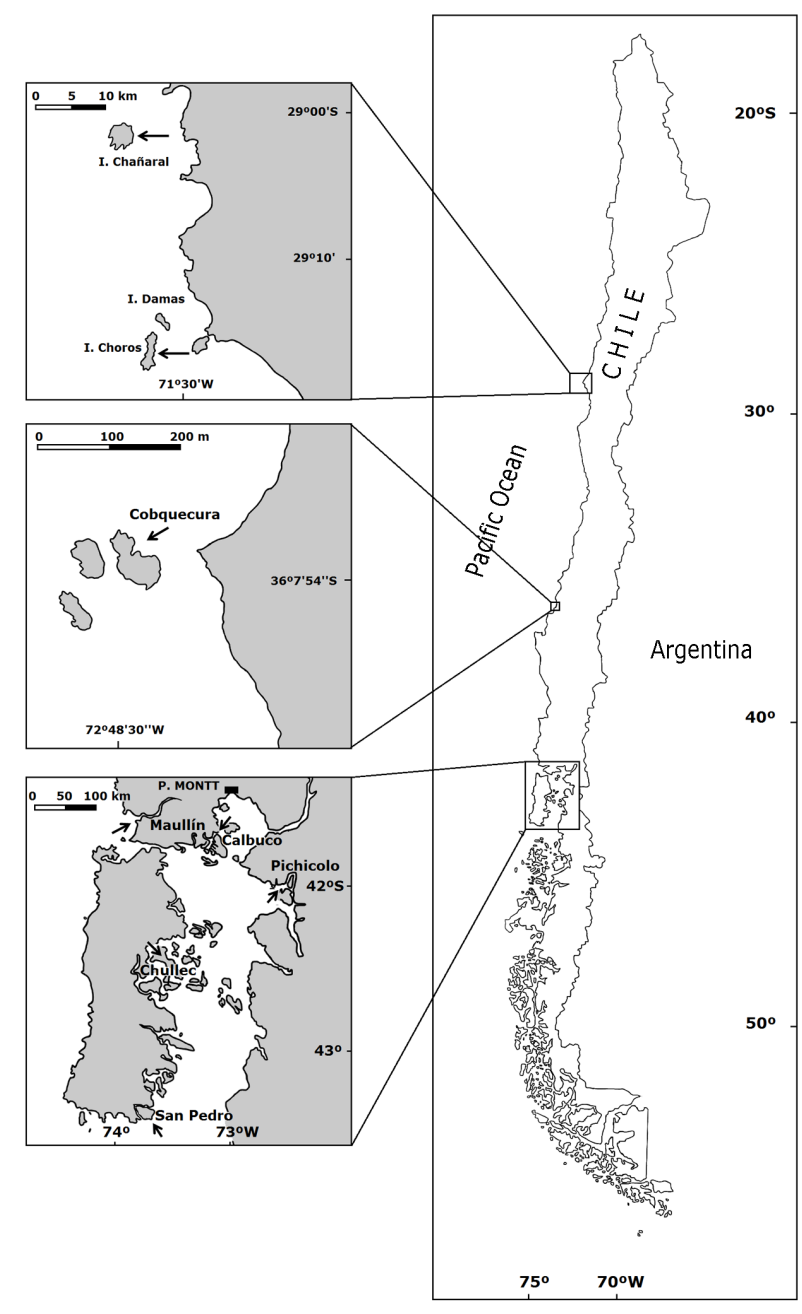

Figure 1. Study area showing the 3 zones of sample collection. Arrows indicate the location of the colonies / Área de estudio en que se indican las 3 zonas de muestreo. Las flechas indican la ubicación de las colonias

standard, respectively. The standards are Vienna-Pee Dee Belemnite limestone (VPDB) for carbon and atmospheric $\mathrm{N}_{2}$ for nitrogen. The units are expressed as parts per thousand or per mil (\%o).

\section{Data analysis}

The potential prey species were pooled into functional groups, which were defined according to both similarity in the isotopic values and ecological function of prey items. The number of groups for each zone, and the species that were included in each group are indicated in Table 1. To determine the relative contribution of the prey groups to the diet of the SASL, we used the Bayesian stable isotope mixing model MixSIR (Moore \& Semmens 2008). 
Table 1. Mean individual and group values of $\delta^{13} \mathrm{C}$ and $\delta^{15} \mathrm{~N}$ and their standard deviations (SD) of the potential prey species of the South American Sea Lion in northern, central and southern zones of Chile and sample number analyzed / Valores promedio individuales y grupales de $\delta^{13} \mathrm{C}$ y $\delta^{15} \mathrm{~N}$ y sus desviaciones estándar (SD) de potenciales especies presa del lobo marino común en la zona norte, centro y sur de Chile y número de muestras analizadas de cada grupo (n)

\begin{tabular}{|c|c|c|c|c|c|c|c|}
\hline \multirow[t]{2}{*}{ Zone } & \multirow{2}{*}{$\begin{array}{l}\text { Prey } \\
\text { group }\end{array}$} & \multirow[t]{2}{*}{ Prey } & \multirow[t]{2}{*}{$n$} & \multicolumn{2}{|c|}{ Individual values } & \multicolumn{2}{|c|}{ Group values } \\
\hline & & & & $\delta^{13} \mathrm{C} \pm \mathrm{SD}$ & $\delta^{15} \mathrm{~N} \pm \mathrm{SD}$ & $\delta^{13} \mathrm{C} \pm \mathrm{SD}$ & $\delta^{15} \mathrm{~N} \pm \mathrm{SD}$ \\
\hline \multirow[t]{9}{*}{ Northern } & N1 & $\mathrm{Ta}$ & 6 & $-17.2 \pm 0.4$ & $19.7 \pm 0.6$ & $-17.0 \pm 0.4$ & $19.6 \pm 0.4$ \\
\hline & & $\mathrm{Tm}$ & 4 & $-16.9 \pm 0.5$ & $19.5 \pm 0.2$ & & \\
\hline & $\mathrm{N} 2$ & $\mathrm{Cg}$ & 3 & $-16.4 \pm 0.6$ & $20.2 \pm 0.1$ & $-16.4 \pm 0.6$ & $20.1 \pm 0.2$ \\
\hline & & $\mathrm{Sf}$ & 3 & $-16.4 \pm 0.9$ & $20.0 \pm 0.2$ & & \\
\hline & N3 & Mo & 2 & $-15.5 \pm 0.9$ & $20.3 \pm 0.2$ & $-15.5 \pm 0.9$ & $20.3 \pm 0.2$ \\
\hline & $\mathrm{N} 4$ & Gc & 5 & $-17.0 \pm 0.3$ & $19.2 \pm 0.6$ & $-17.2 \pm 0.4$ & $19.4 \pm 0.8$ \\
\hline & & Sl & 3 & $-17.4 \pm 0.4$ & $19.6 \pm 1.3$ & & \\
\hline & N5 & $\mathrm{Pa}$ & 4 & $-16.1 \pm 0.7$ & $19.6 \pm 1.9$ & $-16.1 \pm 0.7$ & $19.6 \pm 1.9$ \\
\hline & N6 & Ic & 3 & $-16.5 \pm 0.6$ & $18.4 \pm 1.2$ & $-16.5 \pm 0.6$ & $18.4 \pm 1.2$ \\
\hline \multirow[t]{8}{*}{ Central } & $\mathrm{C} 1$ & $\mathrm{Sb}$ & 8 & $-16.6 \pm 0.4$ & $15.7 \pm 0.7$ & $-16.6 \pm 0.4$ & $15.7 \pm 0.7$ \\
\hline & $\mathrm{C} 2$ & $\mathrm{Mg}$ & 4 & $-16.2 \pm 0.2$ & $16.9 \pm 0.3$ & $-16.2 \pm 0.2$ & $16.9 \pm 0.3$ \\
\hline & $\mathrm{C} 3$ & $\mathrm{~Pa}$ & 2 & $-15.5 \pm 0.1$ & $18.0 \pm 0.6$ & $-15.2 \pm 0.4$ & $17.9 \pm 0.4$ \\
\hline & & So & 3 & $-14.8 \pm 0.0$ & $17.9 \pm 0.3$ & & \\
\hline & & $\mathrm{Gc}$ & 3 & $-15.4 \pm 0.5$ & $17.7 \pm 0.4$ & & \\
\hline & $\mathrm{C} 4$ & $\mathrm{Ta}$ & 2 & $-17.0 \pm 0.9$ & $18.7 \pm 0.2$ & $-17.0 \pm 0.9$ & $18.7 \pm 0.2$ \\
\hline & $\mathrm{C} 5$ & $\mathrm{Ea}$ & 3 & $-15.5 \pm 0.5$ & $16.6 \pm 0.4$ & $-15.5 \pm 0.5$ & $16.6 \pm 0.4$ \\
\hline & C6 & $\mathrm{Cc}$ & 2 & $-14.6 \pm 0.4$ & $16.5 \pm 1.5$ & $-14.6 \pm 0.4$ & $16.5 \pm 1.5$ \\
\hline \multirow[t]{19}{*}{ Southern } & S1 & $\mathrm{Om}$ & 19 & $-17.4 \pm 0.8$ & $12.9 \pm 1.1$ & $-17.3 \pm 0.8$ & $13.0 \pm 1.1$ \\
\hline & & Ok & 3 & $-16.5 \pm 0.1$ & $-13.0 \pm 0.6$ & & \\
\hline & & Ss & 1 & $-17.3 \pm 0.0$ & $13.9 \pm 0.0$ & & \\
\hline & S2 & $\mathrm{Dg}$ & 2 & $-16.2 \pm 0.1$ & $16.3 \pm 0.2$ & $-16.2 \pm 0.1$ & $16.3 \pm 0.2$ \\
\hline & S3 & $\mathrm{Su}$ & 12 & $-15.6 \pm 0.4$ & $15.3 \pm 0.3$ & $-15.6 \pm 0.4$ & $15.3 \pm 0.3$ \\
\hline & S4 & $\mathrm{Sc}$ & 2 & $-14.7 \pm 0.4$ & $19.2 \pm 0.3$ & $-14.4 \pm 0.4$ & $18.1 \pm 1.1$ \\
\hline & & Ma & 14 & $-14.7 \pm 0.5$ & $18.0 \pm 1.1$ & & \\
\hline & & $\mathrm{Hl}$ & 5 & $-14.5 \pm 0.3$ & $17.3 \pm 1.0$ & & \\
\hline & & Gs & 11 & $-14.2 \pm 0.3$ & $17.7 \pm 0.9$ & & \\
\hline & & $\mathrm{Sa}$ & 6 & $-14.2 \pm 0.2$ & $17.8 \pm 0.5$ & & \\
\hline & & $\mathrm{Mm}$ & 4 & $-14.0 \pm 0.7$ & $18.6 \pm 2.0$ & & \\
\hline & & $\mathrm{Cc}$ & 6 & $-14.1 \pm 0.1$ & $19.0 \pm 0.8$ & & \\
\hline & S5 & $\mathrm{Ta}$ & 7 & $-15.1 \pm 0.3$ & $18.1 \pm 1.0$ & $-15.1 \pm 0.3$ & $17.8 \pm 0.9$ \\
\hline & & $\mathrm{Tm}$ & 3 & $-15.1 \pm 0.4$ & $17.3 \pm 0.4$ & & \\
\hline & S6 & $\mathrm{Pa}$ & 7 & $-14.7 \pm 0.6$ & $16.3 \pm 1.4$ & $-14.1 \pm 1.0$ & $15.9 \pm 1.0$ \\
\hline & & $\mathrm{Ph}$ & 9 & $-14.2 \pm 0.9$ & $16.2 \pm 0.5$ & & \\
\hline & & $\mathrm{Ea}$ & 12 & $-13.7 \pm 1.2$ & $15.6 \pm 1.0$ & & \\
\hline & S7 & Нp & 2 & $-13.6 \pm 0.4$ & $14.3 \pm 0.1$ & $-13.3 \pm 0.6$ & $14.7 \pm 0.7$ \\
\hline & & Cs & 1 & $-12.6 \pm 0.0$ & $15.5 \pm 0.0$ & & \\
\hline
\end{tabular}

Species name: Ta: Thyrsites atun; Tm: Trachurus murphyi; Cg: Cilus gilberti; Sf: Sciaena fasciata; Mo: Menticirrhus ophicephalus; Gc: Genypterus chilensis; S1: Seriola lalandi; Pa: Family Paralichthyidae; Ic: Isacia conceptionis; Sb: Strangomera bentincki; Mg: Merluccius gayi gayi; So: Sebastes oculatus; Ea: Eleginops maclovinus; Cc: Callorhinchus callorhynchus; Om: Oncorhynchus mykiss; Ok: Oncorhynchus kisutch; Ss: Salmo salar; Dg: Dosidicus gigas; Su: Sprattus fuegensis; Sc: Seriolella caerulea; Ma: Merluccius australis; Hl: Helicolenus lengerichi; Gs: Genypterus sp; Sa: Salilota australis; Mm: Mustelus mento; Ph: Paralabrax humeralis; Hp: Homalaspis plana; Cs: Cancer setosus. 
The strength of this program is that it allows the user to incorporate sources of uncertainty, such as variance in the isotopic composition of prey (sources) or estimated error in trophic discrimination factors (TDFs) between consumer and in this zone prey. Isotopic values of SASL were entered individually (for hair and skin), while isotope values of the prey were entered as means $( \pm \mathrm{SD})$. We used tissue-diet TDF values of $2.5 \pm 0.5 \%$ ofor $\delta^{13} \mathrm{C}$ and $3.5 \pm$ $0.5 \%$ for $\delta^{15} \mathrm{~N}$ in the mixing model for hair (Hobson et al. 1996). For skin we used TDFs values of $2.5 \pm 0.5 \%$ and $3.0 \pm 0.5 \%$ or for $\delta^{13} \mathrm{C}$ and $\delta^{15} \mathrm{~N}$, respectively (Newsome et al. 2010a,b). These values are similar to the range reported by Newsome et al. (2010b) in vibrissae of the sea otter Enhydra lutris nereis, as well as within the range of mean enrichment factors estimated for pinniped tissues (Hobson et al. 1996, Lesage et al. 2002). We used a standard deviation of $0.5 \%$ for both $\delta^{13} \mathrm{C}$ and $\delta^{15} \mathrm{~N}$. The results obtained in each analysis were grouped into 5 columns that correspond to the probable contributions of each prey group to the diet of each sea lion $(5,25,50$, 75 and $95 \%$ ). The $50 \%$ percentile was used to represent the mean contribution of each prey species, and the 5 and $95 \%$ percentiles for the inferior and superior range, respectively.

We analyzed potential differences in prey consumption for each study area. The Shapiro-Wilks and Levene tests were used to test normality and homoscedasticity of variances, respectively (Sokal \& Rohlf 2011). When $\delta^{13} \mathrm{C}$ or $\delta^{15} \mathrm{~N}$ values fulfilled these assumptions we used a one way analysis of variance (ANOVA), otherwise we used a Kruskal-Wallis non parametric test. All analyses were performed in STATISTICA 8.0 (StatSoft Inc.), using $\alpha=$ 0.05 as significance level.

\section{Results}

Differences in THE isotope SignATURE AMONG THE STUDIED ZONES

Table 1 presents mean $\delta^{13} \mathrm{C}$ and $\delta^{15} \mathrm{~N}$ values of the prey groups for each of the 3 study zones. For each zone significant differences among isotopic signatures of the prey groups were found: In the northern zone for both, $\delta^{13} \mathrm{C}\left(\mathrm{F}_{6,27}=4.79, P=0.002\right)$ and $\delta^{15} \mathrm{~N}\left(\mathrm{H}_{6,34}=14.27, P=\right.$ $0.026)$, and in the central and southern zones, where the $\delta^{13} \mathrm{C}\left(\mathrm{F}_{5,21}=13.79, P<0.00001 ; \mathrm{H}_{6,126}=85.90, P<0.0001\right.$, respectively $)$ as well as $\delta^{15} \mathrm{~N}\left(\mathrm{H}_{5.27}=21.11, P<0.001 ; \mathrm{H}_{6,126}\right.$ $=55.40, P<0.0001$, respectively) differ significantly.

Potential differences in $\delta^{13} \mathrm{C}$ and $\delta^{15} \mathrm{~N}$ values between sexes for northern and central zones were not tested due to small sample size. In the southern zone, no differences were found between sexes for skin and hair for $\delta^{13} \mathrm{C}\left(\mathrm{H}_{2,35}\right.$ $=5.40, P=0.067 ; \mathrm{F}_{2,22}=1.136, P=0.0339$, respectively) and $\delta^{15} \mathrm{~N}\left(\mathrm{H}_{2,35}=1.951, P=0.377 ; \mathrm{F}_{2,22}=3.52, P=0.05\right.$, respectively).

\section{Diet composition of the South American Sea lion}

In the northern zone, analysis of skin showed that the dominant prey groups in the diet of the SASL were N6 $(19.5 \%)$ and N4 (14.2\%), while analysis of hair showed that N2 $(23.3 \%)$ and N6 (16.8\%) were the most important groups (Table 2). No significant differences in the relevance of the different groups to the diet of the SASL in this zone were found, neither for skin $\left(\mathrm{H}_{6,70}=1.206, P=0.976\right)$ nor for hair $\left(\mathrm{H}_{6,28}=11.542, P=0.073\right)$ (Fig 2a, 2b). In the Central zone, analysis of skin showed that the dominant group was $\mathrm{C} 4$ (40.1\%) followed by C3 (13\%) and C6 (13\%), while analysis of hair indicated that $\mathrm{C} 1(31.1 \%)$ and $\mathrm{C} 4(13.5 \%)$ were the

Table 2. Mean contribution (\%), sample number and contribution range of the prey groups in the diet of the South American sea lion according to analysis of skin and hair. The groups with the greatest contribution in each zone are indicated in bold. The mean contribution of each species was estimated using the mean of the $\mathbf{5 0} \%$ percentile for all individuals / Contribución porcentual (\%), número de muestras y rango de contribución de los grupos presa en la dieta del lobo marino común de acuerdo a los análisis de piel y pelo. Los grupos con mayor contribución en cada zona se destacan. La contribución promedio de cada especie fue estimada usando el promedio del percentil $50 \%$ para todos los individuos

\begin{tabular}{lcccccc}
\hline Zone & $\begin{array}{l}\text { Prey } \\
\text { group }\end{array}$ & $n$ & \multicolumn{2}{c}{ Skin } & \multicolumn{2}{c}{ Hair } \\
& & & Mean \pm SD & Range & Mean \pm SD & Range \\
\hline \multirow{2}{*}{ Northern } & N1 & 10 & $12.8 \pm 4.0$ & $0.4-55.6$ & $9.8 \pm 5.9$ & $0.3-69.6$ \\
& N2 & 6 & $11.7 \pm 4.4$ & $0.3-50.2$ & $\mathbf{2 3 . 3} \pm \mathbf{3 1 . 7}$ & $0.2-48.0$ \\
& N3 & 2 & $10.3 \pm 4.9$ & $0.2-48.7$ & $4.5 \pm 1.3$ & $0.2-25.0$ \\
& N4 & 8 & $14.2 \pm 3.6$ & $0.5-82.8$ & $15.5 \pm 8.1$ & $0.5-79.1$ \\
& N5 & 4 & $12.8 \pm 3.6$ & $0.3-76.0$ & $6.7 \pm 2.9$ & $0.2-62.6$ \\
& N6 & 3 & $\mathbf{1 9 . 5} \pm \mathbf{1 5 . 7}$ & $0.6-84.0$ & $16.8 \pm 12.0$ & $0.3-73.3$ \\
Central & C1 & 8 & $5.7 \pm 2.2$ & $0.1-31.1$ & $\mathbf{3 1 . 0} \pm \mathbf{1 6 . 3}$ & $0.7-82.3$ \\
& C2 & 4 & $8.3 \pm 3.3$ & $0.2-44.0$ & $11.9 \pm 3.6$ & $0.4-53.8$ \\
& C3 & 8 & $13.0 \pm 5.0$ & $0.3-59.7$ & $7.7 \pm 3.9$ & $0.3-50.3$ \\
& C4 & 2 & $\mathbf{4 0 . 1} \pm \mathbf{1 5 . 8}$ & $1.6-89.3$ & $13.5 \pm 10.8$ & $0.3-54.1$ \\
& C5 & 3 & $6.9 \pm 3.0$ & $0.2-42.6$ & $10.9 \pm 3.5$ & $0.3-51.4$ \\
& C6 & 2 & $13.0 \pm 8.8$ & $0.4-64.6$ & $12.2 \pm 6.7$ & $0.2-54.9$ \\
& S1 & 23 & $11.9 \pm 14.1$ & $0.2-81.1$ & $\mathbf{2 0 . 7} \pm \mathbf{1 6 . 7}$ & $0.4-83.7$ \\
& S2 & 2 & $11.9 \pm 4.3$ & $0.4-59.2$ & $10.6 \pm 5.2$ & $0.3-63.5$ \\
& S3 & 12 & $8.1 \pm 2.8$ & $0.3-46.7$ & $10.7 \pm 2.8$ & $0.3-46.8$ \\
& S4 & 48 & $19.9 \pm 10.3$ & $0.3-68.3$ & $8.5 \pm 4.0$ & $0.2-50.0$ \\
& S5 & 10 & $\mathbf{2 0 . 8} \pm \mathbf{9 . 2}$ & $0.3-72.1$ & $8.9 \pm 4.2$ & $0.2-53.1$ \\
& S6 & 28 & $7.8 \pm 2.5$ & $0.3-41.9$ & $10.8 \pm 4.1$ & $0.2-48.2$ \\
& S7 & 3 & $5.9 \pm 3.8$ & $0.2-46.1$ & $14.7 \pm 9.3$ & $0.2-55.6$ \\
\hline \multirow{6}{*}{ Southern } & & & & & &
\end{tabular}


most important prey groups. Significant differences were found in the contribution to the diet among some of the groups (Fig. 2c, 2d). Finally, in the Southern zone the analysis of skin indicated that the most important prey groups were S5 (20.8\%) and S4 (19.9\%), while for hair data the relevant groups were S1 (20.7\%) and S7 (14.7\%). Also, significant differences were found in the contribution to the diet among some of the group, both for skin and hair (Fig. 2e, 2f).

In 2 of the 3 study areas there were variations in diet composition among individuals; in $10 \mathrm{SASL}$, the consumption of just one prey group was $\geq 50 \%$. For example, in the Central Zone one individual was estimated to have consumed $67 \% \mathrm{C} 4$ (snoek) and another one $65 \%$ C1 (Araucanian herring), whereas in the Southern Zone one individual consumed more than $70 \% \mathrm{~S} 1$ (farm-raised salmonids), while in others salmonids were consumed in trace amounts $(<4 \%)$.

\section{Discussion}

\section{SPATIAL DIFFERENCES IN DIET COMPOSITION}

As expected, in the 3 study zones the main prey items in the SASLs diet were fish, which coincides with the reports of other authors, both for Chile and other countries (Aguayo \& Maturana 1973, Vaz-Ferreira et al. 1982, George-Nascimento et al. 1985, Crespo et al. 1997, Koen Alonso et al. 2000). The only exception was skin in the southern zone, where S6 (crabs) was also an important prey item.

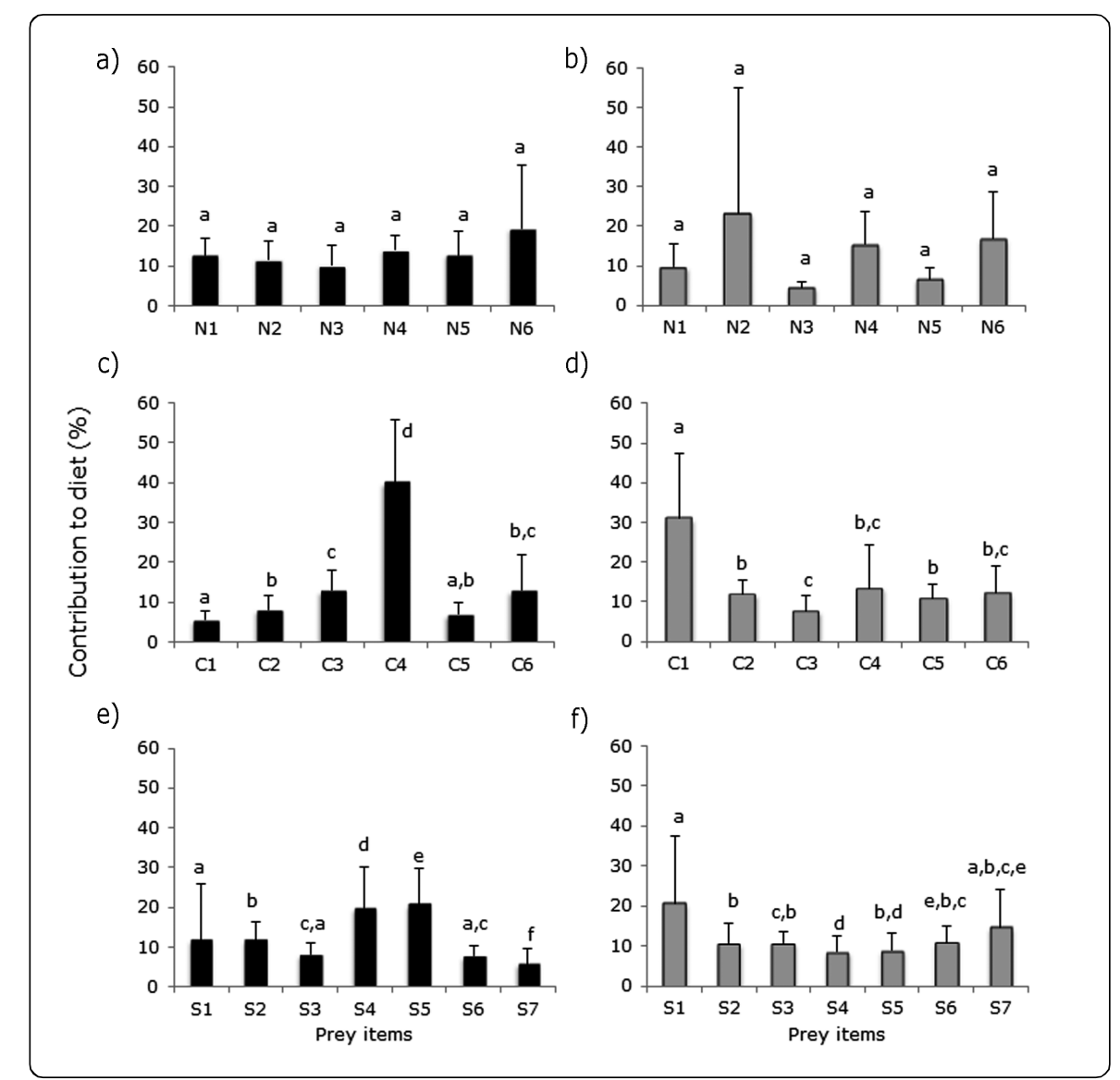

Figure 2. M ean $( \pm S D)$ porcentual contribution of the different prey groups into the diet of the South American sea lion (Otaria flavescens) in the 3 study areas, and for skin and hair analyses. Black bars (a, c, e) showed the skin results for the northern, central, and southern zones, respectively, while grey bars $(b, d, f)$ showed the hair results for the same zones. Same letters indicated no significant differences among groups / Contribución porcentual promedio de los diferentes grupos de presas en la dieta del lobo marino común (Otaria flavescens) en las 3 zonas de estudio, y para análisis de piel y pelo. Las barras negras (a, c, e) muestran los resultados de los análisis de piel en las zonas norte, centro y sur, respectivamente, mientras que las barras grises $(b, d, f)$ muestran los resultados de pelo en las mismas zonas. Las letras iguales indican que no existen diferencias significativas entre los grupos 
In the northern zone Isacia conceptionis and Cilus gilberti were the most important prey item for the SASLs diet, both for skin and hair analyses. Unfortunately, for this zone there are no previous studies with which to compare our results. Aguayo \& Maturana (1973) and Sielfeld et al. (1997) studied the diet composition of SASL using stomach contents in the zone of Valparaíso and in the extreme north (Iquique), respectively. Aguayo \& Maturana (1973) found that the main prey items of sea lions were Sebastes oculatus and Merluccius gayi gayi, while Sielfeld et al. (1997) found that Engraulis ringens and Loligo gahi were the most important prey. However, the results of these studies are not strictly comparable to our study, since they sampled from different fishing zones. Additionally, in our study no samples of M. gayi gayi, E. ringens or L. gahi were collected, since there is almost no catches of these species in areas close to the study zone (SERNAPESCA 2010). In future studies it would be recommended to collect an even larger number of potential prey species in order to be able to compare with previous studies.

The main prey consumed by the SASL in the central zone, according to both skin and hair analyses, was the Thyrsites atun. This may be explained because the T. atun is one of the main species captured in this zone; landings of this species in the VIII Region represented $38.4 \%$ of the national landing reports (SERNAPESCA 2011). T. atun are also captured as by-catch in Strangomera bentincki and $E$. ringens fisheries, and sea lions have been observed entering to fish nets to feed on this species (Andrea Nadeau pers. com.). The analysis of hair indicated that Strangomera bentincki is another important dietary item in this zone, reaching a mean value of around $30 \% . S$. bentincki and $E$. ringens fisheries are the main commercial activity of small pelagic fisheries in central Chile $\left(34^{\circ}\right.$ $\left.40^{\circ} \mathrm{S}\right)$. Strangomera bentincki are captured mainly during the first 6 months of the year, associated with the high seasonality in the abundance and availability of this species (Gatica et al. 2007). Given that the analysis of hair represents the diet consumed in austral autumn months (see below), we infer that sea lions take advantage of the higher abundance and availability of this species in this period of the year.

In the southern zone, farm-raised salmonids were the most important prey group for sea lions in the analysis of hair $(20.7 \%)$. In the case of skin, the principal prey groups were S4 (Seriolella caerulea, Merluccius australis, Helicolenus lengerichi, Genypterus sp., Salilota australis, Mustelus mento, Callorhinchus callorhynchus) and S5 (Thyrsites atun, Trachurus murphyi) which corresponded to demersal and pelagic fish, respectively (Table 1). Unfortunately, there are no previous studies of the diet composition of the SASL in this zone to compare with our results. However, Sepúlveda \& Oliva (2005) and Vilata et al. (2010) indicated a strong interaction between the SASL and salmon farming in the study area, which would explain the high consumption of this diet item, representing $>60 \%$ of the diet for same individuals. Also, in the case of demersal and pelagic fish, support of consumption of these preys was obtained from Pavés $e t$ al. (pers. comm.), who evidenced a strong operational interaction between the SASL and the commercial fisheries of demersal and pelagic species in southern Chile, which captured the same species that we included in our study (e.g., Thyrsites atun, Callorhinchus callorhynchus, Genypterus spp.).

\section{TEMPORAL DIFFERENCES IN DIET COMPOSITION}

The central zone is the only sector in which there is a previous study with which to compare, and the results of this study differ from those reported by other authors. Using stomach content analysis, George-Nascimento et al. (1985) found that the most important preys consumed by the SASL were the South Pacific hake (Merluccius gayi gayi) and the pink cusk-eel (Genypterus blacodes). Although samples of hakes were collected and incorporated in our study, it was not an important item in the diet of SASL. The reason may be that the biomass of M. gayi gayi decreased drastically as a consequence of overexploitation after the years 2002-2005 (SUBPESCA 2010). Hückstädt et al. (2007) found that in this same zone the SASL fed mainly on T. murphyi. However, our study is not comparable with that of Hückstädt et al. (2007), since we were not able to obtain samples of $T$. murphyi, due to there was no landings of this species during the sampling period. As in the case of the $M$. gayi gayi, the scarcity of this species is due to overfishing; there has been a large decrease in national landings, from 1.3 million tons in 2007 to 0.25 million tons in 2011 (SERNAPESCA 2011). These temporal comparisons may suggest that the drastic decrease of these 2 resource species modified the diet composition of the SASL in recent decades.

It is important to note that the differences in the findings of this study with the results of GeorgeNascimento et al. (1985) may also be due to the particular characteristics of the different methodologies. Stomach content analysis only reveals the main prey items 
consumed in the past few days, while the analysis of stable isotopes is very sensitive to the fractioning factors used in the analysis of the diet (Newsome et al. 2010a). These factors should be taken into account in comparing studies which use different methodologies.

In addition to long-term (years) temporal variation in the diet composition of the SASL, we also found temporal differences in the short term (months) in the central zone. The importance of the $S$. bentincki in hair may be related to the variability in specific metabolic renewal rates for each tissue, from which information at different time scales may be obtained (Hobson et al. 1996, Kelly 2000). Consumption of a given prey species is reflected into the diet in the period in which the tissue is generated. In the case of hair, its shedding in the SASL occurs in austral autumn (Luis Hückstädt pers. com.), thus the values of $\delta^{13} \mathrm{C}$ and $\delta^{15} \mathrm{~N}$ in this tissue reflect the diet consumed during this period of time. Autumn months are those in which herring extraction was highest in the central zone of the country (SERNAPESCA 2010), which could explain why this species was predominant in the diet in the analysis of hair. In the absence of $S$. bentincki, the skin analysis indicated that almost $50 \%$ of the diet was composed by $T$. atun, which suggests that this species replaced the $S$. bentincki when the former was not available.

The above suggests that the sea lion is capable of vary its diet not only as a response to the availability of its preys but also given to temporal variation in the abundance of the same preys. Intra-specific temporal variation in diet has also been reported in other species of sea lions, such as in the northern fur seal Callorhinus ursinus (Kurle \& Worthy 2001), California sea lion Zalophus californianus (Costa et al. 2007), Antartic fur seals Arctocephalus gazella (Cherel et al. 2009) and the Australian sea lion Neophoca cinerea (Costa \& Gales 2003). According to Estes et al. (2003), the overabundance or near extinction of a given prey species may modify the dietary selection of an individual to include or exclude this item, in spite of the high cost this change may entail. Thus the generalist and opportunistic habit of the SASL would allow it to adapt rapidly to this type of change (Cappozzo \& Perrin 2009).

\section{Trophic SPECialization?}

Although the SASL is considered to be a generalist and an opportunistic predator, in this study we found high inter-individual variation in the diet composition of some of the animals sampled in a same zone. For example, we found a high consumption of farm-raised salmonids (> $50 \%$ ) by some animals but almost no consumption $(<4 \%)$ by others. This same generalist/specialist disconnection has also been reported for other species of marine mammals, such as the California sea otter (Enhydra lutris) (Estes et al. 2003). These authors registered a total of 32 prey species for a group of 10 otters; however, each individual otter specialized on feeding on one to 4 species, with very different diets between animals. This foraging behavior has been also reported in different species of otariids, such as in California sea lions (García-Rodríguez \& Aurioles-Gamboa 2004), Antartic fur seals Arctocephalus gazella (Cherel et al. 2009), and Australian sea lions (Lowther \& Goldsworthy 2010, Lowther et al. 2011), defining their trophic habits as 'plastic specialists'.

These inter-individual differences may be interpreted as a way of reducing intraspecific competition, in order to maximize foraging success (Hückstädt et al. 2012). The results of Estes et al. (2003) and Hückstädt et al. (2012), along with those reported here suggest that there may be individual specialization in the diet, at least for some individuals of the SASL, although as a group the species appears to be generalist. Further studies will be necessary to confirm specialization in the diet of the SASL, to determine whether this species reduces intraspecific competition by 'sorting out' resources in order to decrease competition with other individuals and thus optimize feeding (Estes et al. 2003, Hückstädt et al. 2012).

\section{ACKNOWLEDGMENTS}

We thank Rodrigo Moraga, María José Pérez, Pablo Carrasco, Patricia Inostroza and Danilo Alegria for their help in the field, and to Lafayette Eaton for English translation. We also acknowledge Seth Newsome for their valuable correction to an earlier version of the manuscript. We thank the company Salmonoil S.A. for providing us samples of salmon species and Cultivos Marinos Leoman Ltda. for logistic support in the field. This study was funded by projects DIUV-REG 25/2007; Celulosa Arauco and Constitución S.A., INNOVA-CORFO 07CN13IPM170, and Fondecyt $\mathrm{N}^{\circ} 11110081$.

\section{LITERATURE CITED}

Aguayo A \& R Maturana. 1973. Presencia del lobo marino común Otaria flavescens en el litoral chileno. Biología Pesquera 6: 45-75.

Barros NB \& MR Clarke. 2009. Diet. In: Perrin WF, B Würsig \& JGM Thewissen (eds). Encyclopedia of marine mammals, pp. 311-316. Academic Press/Elsevier, Amsterdam. 
Cappozzo HL \& WF Perrin. 2009. South American sea lion Otaria flavescens. In: Perrin WF, B Würsig \& JGM Thewissen (eds). Encyclopedia of marine mammals, pp. 1076-1079. Academic Press/Elsevier, Amsterdam.

Caut S, E Angulo \& F Courchamp. 2009. Variation in discrimination factors $\left(\Delta^{15} \mathrm{~N}\right.$ and $\left.\Delta^{13} \mathrm{C}\right)$ : the effect of diet isotopic values and applications for diet reconstruction. Journal of Applied Ecology 46: 443-453.

Cherel Y, L Kernaléguen, P Richard \& C Guinet. 2009. Whisker isotopic signature depicts migration patterns and multi-year intra- and inter-individual foraging strategies in fur seals. Biology Letters 5: 830-832.

Costa DP \& NJ Gales. 2003. Energetics of a benthic diver: seasonal foraging ecology of the Australian sea lion Neophoca cinerea. Ecological Monographs 73: 27-43.

Costa DP, C Kuhn \& MJ Weise. 2007. Foraging ecology of the California sea lion: Diet, diving behavior, foraging locations, and predation impacts on fisheries resources. California Sea Grant: Research Completion Reports, 41 pp. California Sea Grant College Program, University of California, San Diego.

Crawford K, R McDonald \& S Bearhop. 2008. Applications of stable isotope techniques to the ecology of mammals. Mammal Review 38: 87-107.

Crespo EA, SN Pedraza, SL Dans, M Koen-Alonso, LM Reyes, NA García \& M Coscarella, ACM Schiavini. 1997. Direct and indirect effects of the highseas fisheries on the marine mammal populations in the northern and central Patagonian coast. Journal of Northwest Atlantic Fishery Science 22: 189-207.

Das K, G Lepoint, Y Leroy \& JM Bouquegneau. 2003. Marine mammals from the southern North Sea: feeding ecology data from $\delta^{13} \mathrm{C}$ and $\delta^{15} \mathrm{~N}$ measurements. Marine Ecology Progress Series 263: 287-298.

DeNiro MJ \& S Epstein. 1978. Influence of diet on the distribution of carbon isotopes in animals. Geochimica et Cosmochimica Acta 42: 495-506.

DeNiro MJ \& S Epstein. 1981. Influence of diet on the distribution of nitrogen isotopes in animals. Geochimica et Cosmochimica Acta 45: 341-351.

Estes JA, ML Riedman, MM Staedler, MT Tinker \& BE Lyon. 2003. Individual variation in prey selection by sea otters: patterns, causes and implications. Journal of Animal Ecology 72: 144-155.

Fry B. 2006. Stable isotope ecology, 308 pp. Springer, New York.

García-Rodríguez FJ \& D Aurioles-Gamboa. 2004. Spatial and temporal variation in the diet of the California sea lion (Zalophus californianus) in the Gulf of California, Mexico. Fishery Bulletin 102: 47-62.

Gatica C, M Arteaga, J Giacaman \& P Ruiz. 2007. Tendencias de la biomasa de sardina común (Strangomera bentincki) y anchoveta (Engraulis ringens) en la zona centro-sur de Chile, entre 1991 y 2005. Investigaciones Marinas 35: 13-24.
George-Nascimento M, R Bustamante \& C Oyarzún. 1985. Feeding ecology of the South American sea lion Otaria flavescens: food contents and food selectivity. Marine Ecology Progress Series 21: 135-143.

Hicks BD, DJS Aubin, JR Geraci \& WR Brown. 1985. Epidermal growth in the bottlenose dolphin, Tursiops truncatus. The Journal of Investigative Dermatology 85: 60-63.

Hobson KA. 1993. Trophic relationships among high Arctic seabirds: insights from tissue-dependent stable-isotope models. Marine Ecology Progress Series 95: 7-18.

Hobson KA \& RG Clark. 1992. Assessing avian diets using stable isotopes I: Turnover of ${ }^{13} \mathrm{C}$ in tissues. Condor 94: 181-188.

Hobson KA, JF Piatt \& J Pitocchelli. 1994. Using stable isotopes to determine seabird trophic relationships. Journal of Animal Ecology 63: 786-798.

Hobson KA, DM Schell, D Renouf \& E Noseworthy. 1996. Stable carbon and nitrogen isotopic fractionation between diet and tissues of captive seals: implications for dietary reconstructions involving marine mammals. Canadian Journal of Fisheries and Aquatic Science 53: 528-533.

Hobson KA, JL Sease, RL Merrick \& JR Piatt. 1997. Investigating trophic relationships of pinnipeds in Alaska and Washington using stable isotope ratios of nitrogen and carbon. Marine Mammal Science 13: 114-132.

Hückstädt LA, CP Rojas \& T Antezana. 2007. Stable isotope analysis reveals pelagic foraging by the Southern sea lion in central Chile. Journal of Experimental Marine Biology and Ecology 347: 123-133.

Hückstädt LA, PL Koch, BI McDonald, ME Goebel, DE Crocker \& DP Costa. 2012. Stable isotope analyses reveal individual variability in the trophic ecology of a top marine predator, the southern elephant seal. Oecologia 169: 395406.

Karasov W \& C Martínez del Río. 2007. Physiological ecology. How animals process energy, nutrients, and toxins, 741 pp. Princeton University Press, New Jersey.

Kelly JF. 2000. Stable isotopes of carbon and nitrogen in the study of avian and mammalian trophic ecology. Canadian Journal of Zoology 78: 1-27.

Koen Alonso M, EA Crespo, SN Pedraza, NA García \& M Coscarella. 2000. Food habits of the South American sea lion, Otaria flavescens, off Patagonia, Argentina. Fishery Bulletin 98: 250-2.

Kurle CM \& GAJ Worthy. 2001. Stable isotope assessment of temporal and geographic differences in feeding ecology of northern fur seals (Callorhinus ursinus) and their prey. Oecologia 126: 254-265.

Lesage V, MO Hammill \& KM Kovacs. 2002. Diet tissue fractionation of stable carbon and nitrogen isotopes in phocid seals. Marine Mammal Science 18: 182-193. 
Lowther AD \& SD Goldsworthy. 2010. Detecting alternate foraging ecotypes in Australian sea lion (Neophoca cinerea) breeding colonies using stable isotope analysis. Marine Mammal Science 27: 567-286.

Lowther AD, RG Harcourt, DJ Hamer \& SD Goldsworthy. 2011. Creatures of habit: foraging habitat fidelity of adult female Australian sea lions. Marine Ecology Progress Series 443: 249-263.

Martínez del Río C, N Wolf, SA Carleton \& LZ Gannes. 2009. Isotopic ecology ten years after a call for more laboratory experiments. Biological Reviews 84: 91-111.

Moore JW \& BX Semmens. 2008. Incorporating uncertainty and prior information into stable isotope mixing models. Ecology Letters 11: 470-480.

Naya D, R Vargas \& M Arim. 2000. Análisis preliminar de la dieta del león marino del sur (Otaria flavescens) en Isla de Lobos, Uruguay. Boletín de la Sociedad de Zoología, Uruguay (2a Época) 12: 14-21.

Newsome SD, MT Tinker, DH Monson, OT Oftedal, K Ralls, MM Staedler, ML Fogel \& JA Estes. 2009. Using stable isotopes to investigate individual diet specialization in California sea otters (Enhydra lutris nereis). Ecology 90: 961-974.

Newsome SD, MT Clementz \& PL Koch. 2010a. Using stable isotope biogeochemistry to study marine mammal ecology. Marine Mammal Science 26: 509-572.

Newsome SA, GB Bentall, MT Tinker, OT Oftedal, K Ralls, JA Estes \& ML Fogel. 2010b. Variation in $\delta^{13} \mathrm{C}$ and $\delta^{15} \mathrm{~N}$ diet-vibrissae trophic discrimination factors in a wild population of California sea otters. Ecological Applications 20: $1744-1752$.

Orr AJ, GR VanBlaricom, RL DeLong, VH Cruz-Escalona \& SD Newsome. 2011. Intraspecific comparison of diet of California sea lions (Zalophus californianus) assessed using fecal and stable isotope analyses. Canadian Journal of Zoology 89: 109-122.

Parnell AC, R Inger, S Bearhop \& AL Jackson. 2010. Source partitioning using stable isotopes: Coping with too much variation. PLoS ONE 5(3): e9672. <doi:10.1371/ journal.pone.0009672>
Phillips DL \& JW Gregg. 2003. Source partitioning using stable isotopes: coping with too many sources. Oecologia 136: 261-269.

Sepúlveda M \& D Oliva. 2005. Interactions between South American sea lions Otaria flavescens (Shaw) and salmon farms in southern Chile. Aquaculture Research 36: 10621068.

SERNAPESCA. 2010. Anuario estadístico de pesca. Desembarque de peces por especie entre 2000-2010. Servicio Nacional de Pesca, Valparaíso. <http//www.sernapesca.cl/index.php ?option $=$ com_remository \&Itemid $=246 \&$ func $=$ select\& id $=548$ \&orderby $=2$ \&page $=1>$

SERNAPESCA. 2011. Anuario estadístico de pesca. Desembarque artesanal por especie y región 2011. Servicio Nacional de Pesca, Valparaíso. <h t t p : / / w w w. se rn a pe s ca.cl/index.ph p?option $=$ com_remository\&Itemid $=246 \&$ func $=$ fileinfo\&id $=6313>$

Sielfeld W, C Guerra, LR Durán, E Acuña, A AguayoLobo, M Sepúlveda, F Palma, A Malinarich, G Cerda, A Bolvarán, R Grau, X Veloso, Y Guerra, M Vargas, N Amado, R Peredo \& J Galáz. 1997. Monitoreo de la pesquería y censo del lobo marino común en el litoral de la I-IV Regiones. Informe Final Proyecto FIP 95-28: 1-105. <http://www.fip.cl/Archivos/Hitos/Informes/inffinal\%209528.pdf $>$

Sokal RR \& FJ Rohlf. 2011. Biometry: The principles and practice of statistics in biological research, 937 pp. W.H. Freeman and Company, New York.

SUBPESCA. 2010. Cuota global anual de captura de merluza común (Merluccius gayi gayi), año 2011. Informe Técnico (R. Pesq.), 124/2010: 1-56. Subsecretaría de Pesca, Valparaíso.

Tieszen LL, TW Boutton, KG Tesdahl \& NA Slade. 1983. Fractionation and turnover of stable carbon isotopes in animal tissues: implications for $\delta^{13} \mathrm{C}$ analysis of diet. Oecologia 57: 32-37.

Vaz-Ferreira R. 1982.Otaria flavescens (Shaw), South American sea lion. Mammals in the Seas. FAO Fisheries Series 5: 477-496. FAO, Rome.

Vilata J, D Oliva \& M Sepúlveda. 2010. The predation of farmed salmon by South American sea lions (Otaria flavescens) in southern Chile. ICES Journal of Marine Science 6: 1-8. 